Will Additional Federal Enforcement Improve the Performance of Pipelines in the U.S.?

\author{
Sarah Stafford \\ College of William and Mary
}

College of William and Mary

Department of Economics

Working Paper Number 144

Current Version: August 2013 
COLLEGE OF WILLIAM AND MARY

DEPARTMENT OF ECONOMICS

WORKING PAPER \# 144

August 2013

\title{
Will Additional Federal Enforcement Improve the Performance of Pipelines in the U.S.?
}

\begin{abstract}
This paper provides the first empirical analysis of the effectiveness of regulatory enforcement in increasing the environmental and safety performance of U.S. natural gas and hazardous liquid pipeline operators. The analysis combines data on federal regulatory inspections, enforcement actions, and penalties with data on injuries, fatalities, property damage, and barrels of product lost through pipeline "incidents" for 2006-2011 for the 344 largest pipeline operators in the U.S. The results of the analysis do not provide compelling evidence that either federal inspections or civil penalties are particularly effective in increasing performance; however, the number of federal cases initiated against an operator does have a significant effect on many forms of performance, although not for incidents in general. The results also suggest that some targeting of federal enforcement resources is based on past performance, but there may be room for even more effective targeting. Finally, the analysis reveals interesting patterns between state and federal enforcement efforts.
\end{abstract}

Keywords: Regulation, Environmental Performance, Enforcement, Pipelines

JEL Classification: K42, L95

Sarah Stafford

Department of Economics

College of William and Mary

Williamsburg, VA 23187-8795

slstaf@wm.edu 


\section{Will Additional Federal Enforcement Improve the Performance of Pipelines in the U.S.?}

\section{Introduction}

Over the past several years, the role that oil and natural gas pipelines might play in increasing the U.S.'s energy independence has gained significant attention. In particular, TransCanada's proposed Keystone XL Pipeline has been the subject of heated debate between those that believe the project is a critical part of the U.S.'s energy security strategy and will have a positive effect on the country's economy and those that believe the project imposes unacceptable risks for the natural environment including devastating sensitive environments and polluting important water sources. A number of relatively recent events have reinforced the arguments that pipelines pose serious threats to human health and the environment: in September of 2010 a natural gas pipeline explosion in San Bruno, California resulted in a massive fire that killed eight people, injured dozens of others, and destroyed over 100 homes and in July of 2011 an Exxon Mobil pipeline rupture spilled over 1,000 barrels of oil into the scenic Yellowstone River.

In late 2011, the U.S. Congress approved and President Obama signed the Pipeline Safety, Regulatory Certainty, and Job Creation Act to improve the performance of pipelines. The act was passed during the $112^{\text {th }}$ Congress, one of the least productive - if not the least

productive - legislative session in recent history [1]. The act drew unanimous support from both parties in part because of public outcry over the San Bruno explosion and the Yellowstone River spill. However, the act was a compromise and did not include all of the recommended policy changes that were proposed by the National Transportation Safety Board for increasing pipeline safety [2]. The main provisions of the act are an increase in 
funding for federal inspections of pipelines (the "Job Creation" part of the act) as well as an increase in the fines associated with violations of pipeline regulations. In accordance with the act, the administration's 2013 fiscal year budget increased funding for the Pipeline and Hazardous Safety Materials Administration by 60 percent and added 120 new federal inspectors.

While numerous studies have assessed the effectiveness of federal enforcement in improving compliance with general environmental regulations, to my knowledge there has never been a systematic evaluation of the effect of federal enforcement efforts on pipeline performance. Thus it is not clear whether the Pipeline Safety, Regulatory Certainty, and Job Creation Act will actually accomplish its stated goal of increasing pipeline performance. In particular, because the act was prompted by public pressure to do something about pipeline performance, as May [3] points out, the compromise solution may not fully address the underlying regulatory failure. The goal of this paper is to provide the first empirical analysis of the effect that federal pipeline enforcement on pipeline performance. The results of this analysis should provide insight into whether the changes mandated under the Pipeline Safety, Regulatory Certainty, and Job Creation Act are likely to achieve their goal of improving pipeline safety.

\section{Background on the Pipeline Industry}

Many liquid products are most cost-effectively transported via pipelines. However, many of the products transported by pipeline can pose significant threats to human health and the environment if leaked or released from the pipeline. Although pipelines are designed and constructed to maintain structural integrity since the transported materials 
have intrinsic value (unlike many effluent substances, such as hazardous wastes or byproducts), many factors make it difficult to avoid leaks and other releases during a pipeline's lifetime. Natural disasters, such as flooding, earthquakes, and storms, can result in pipeline failures, as can accidental human, machine, and animal intrusions. Additionally, pipelines may develop leaks or ruptures due to corrosion from the materials being transported or material fatigue from fluctuating temperature and pressure conditions.

In the U.S. over 2.5 million miles of pipelines transport natural gas, petroleum products and other hazardous liquids. Overall, pipelines are a relatively safe mode of transportation compared to alternatives such as tankers and rail cars, and the pipeline transmission safety record has improved significantly over time. However, more than 100 significant pipeline releases occur each year, and deaths from pipeline accidents are, unfortunately, not rare occurrences.

Prior to 1968, pipelines were not subject to safety or environmental regulations. In 1968, Congress established the Office of Pipeline Safety (OPS), a division of the Department of Transportation (DOT), to develop and implement safety regulations for natural gas pipelines. Hazardous liquid pipelines were added to OPS's portfolio in 1979, but until 2002 OPS was generally seen as ineffectual, with weak enforcement and ineffective rules [4]. In 2002, Congress passed the Pipeline Safety Improvement Act, which increased penalties and enforcement authority, and limited OPS discretion.

OPS sets the federal standards with which all pipeline operators must comply. As is true with many other regulations, states can and do pass supplemental regulations. Additionally, pipelines in "high consequence" areas are subject to a stricter set of controls due to the increased risk for damage to human health or the environment. Both federal and 
state regulators enforce OPS regulations. In theory, standard inspections are conducted every couple of years on all pipelines and more often on pipelines with higher potential risks. If a pipeline crosses state borders, enforcement generally falls to OPS, while states inspect most intrastate lines. However, not all states have been certified or approved to conduct intrastate inspections; in unapproved states federal regulators conduct all pipeline inspections. Conversely, OPS has authorized some states to act as its agent and inspect the sections of interstate pipelines that run through the state in addition to intrastate pipelines. To complement formal enforcement, regulated pipelines must also self-inspect and report any violations discovered during the course of required inspections.

OPS is a relatively small agency. In 2011 prior to the passage of the Pipeline Safety, Regulatory Certainty, and Job Creation Act, there were under 120 inspectors working for OPS out of five regional offices (Trenton, NJ; Atlanta, GA; Kansas City, MO; Houston, TX; and Denver, C0) [5]. An additional 300 state inspectors carry out the majority of pipeline inspections. Standard inspections are designed to ensure that operation and maintenance procedures, abnormal and emergency operating procedures, damage prevention and public education procedures, and pipeline installation, connection, repair, and operations are in compliance with the relevant regulations. Construction inspections include a review of material and component design specifications, welding procedures and welder qualifications, corrosion protection, and installation as well as post-construction testing. Integrity management inspections are designed to determine whether an operator uses all available information about its pipeline system to assess risks and takes appropriate action to mitigate those risks. 
OPS can initiate an enforcement case when an inspection identifies a violation of pipeline regulations or in response to an accident. The type of enforcement action taken depends on the significance of the violation. Minor problems occurring for the first time may only receive a warning letter, while more significant violations may require a compliance order that specifies actions the operator must take to come into compliance (e.g., requiring operators to replace pipeline sections or implement corrosion control and remediation strategies) or a civil penalty. Civil penalties are generally reserved for serious violations leading to deaths, injuries, or significant environmental damage. Regulators may impose civil penalties as severe as $\$ 100,000$ for each day a violation existed, up to a maximum of $\$ 1,000,000$. Since 2008 , OPS has proposed over $\$ 21$ million in civil penalties [6].

There are currently 2,705 regulated pipeline operators in the U.S. Of these, 1,921 operate less than 10 miles of pipeline, 440 operate between 10 and 100 miles of pipeline, and 344 operate 100 miles or more of pipeline. In 2010, 22 fatalities and 109 injuries were attributed to pipeline incidents. Of course these numbers are quite variable - over the last 20 years, the number of fatalities has ranged from a low of 7 in 2001 to a high of 53 in 1996. Similarly the number of injuries has ranged from a low of 36 in 2006 to a high of 127 in 1996. Of course injuries and deaths are not the only damages that result from poor pipeline performance. In 2010, pipeline incidents resulted in almost $\$ 1.4$ billion dollars of property damage and almost 175,000 barrels of spilled hazardous liquids. On the enforcement side, in 2010 federal regulators conducted around 600 pipeline inspections, initiated just over 200 enforcement actions and assessed over $\$ 4.5$ million dollars in penalties. During the same time period state regulators logged almost 38,000 inspection 
days, discovered almost 14,000 violations, initiated over 4,000 enforcement actions, and assessed over \$13 million dollars in penalties.

\section{Related Literature}

The objective of this paper is to better understand the role that federal inspections and enforcement actions play in increasing pipeline performance and compliance. To my knowledge, there are no existing papers that explicitly model compliance with pipeline regulations, either theoretically or empirically. ${ }^{1}$ However, there is a large literature examining compliance with environmental regulations more broadly, and I use this as a starting point for the analysis.

The traditional economic view of environmental compliance and performance assumes that a regulated entity's decision to comply with environmental regulations is a rational one based on the objective of profit maximization. The basic framework for these models is Becker's [8] paper on the economics of crime, which was adapted by Russell, Harrington, and Vaughan [9] to provide a comprehensive application to environmental regulation. While a number of interesting variations on these models have been developed over the past two decades to allow for various complexities such as imperfect information, self-reporting, principal-agent relationships, and dynamic settings, in all of these deterrence-based models compliance and performance are ultimately improved by increasing the expected cost of noncompliance - either by increasing the likelihood that a violator gets caught or by increasing the level of sanctions associated with violations.

${ }^{1}$ There are a number of papers that analyze pipeline incidents from an engineering perspective to better understand the distribution of pipeline failures (see, for example Sosa and Alvarez-Ramirez [7]). These papers do not examine regulatory structures or policies. 
While deterrence-based models dominate the economics literature on environmental enforcement, a number of papers in other fields have recognized alternative motivations for compliance or reasons for nonperformance. For example, a regulated entity may comply with regulations out of an inherent sense of duty to obey rules or because of social pressure, even if the probability of detection is very low or the punishment for a violation is negligible. Alternatively, even with severe sanctions or a high probability of detection, if a regulated entity's managers do not understand the regulatory requirements, or have poor internal controls, even well intentioned regulated entities may still violate regulations. Finally, some violations, such as those triggered by extreme weather, may occur despite a regulated entity's fully compliant operations. In such cases, deterrencebased measures would prove generally ineffective at increasing performance. Of course, while some theoretical models focus on a particular motive underlying the compliance decision, in practice the compliance decision is likely to depend on a number of different objectives and factors that differ across facilities.

According to Gray and Shimshack [10], most policy-makers and scholars believe that an enforcement regime of inspections and sanctions is generally effective at increasing compliance with environmental regulations, and most regulated entities cite rigorous monitoring and enforcement as a primary motivator of their environmental compliance decisions. A number of empirical analyses confirm these beliefs. For example, Gray and Deily [11] and Gray and Shadbegian [12] examine air pollution compliance for steel mills and pulp and paper mills in the U.S., respectively, and find that both inspections and enforcement actions have a statistically significant positive impact on compliance. Looking at compliance with U.S. water regulations, Earnhart [13] and Glicksman and Earnhart [14] 
similarly find that inspections and sanctions deter violations and reduce emissions at water treatment plants and chemical facilities, respectively. Stafford [15] shows that compliance inspections and penalties for violations have a significant deterrent effect on violations at facilities subject to hazardous waste regulations. ${ }^{2}$

These results from the environmental compliance literature echo findings in other regulatory areas. In particular, a number of papers examine the deterrent effect of Occupational Safety and Health Administration (OSHA) inspections and sanctions on workplace injuries. Many of these papers find that inspections and sanctions do deter injuries, although the effects of deterrence depend significantly on the characteristics of the regulated entity being inspected or sanctioned and whether the inspection results in a sanction $[16,17,18]$. The goal of this paper is to add evidence from another closely related regulatory sector, pipelines, on the deterrent effect of federal inspections and enforcement actions in increasing compliance and performance.

\section{Framework for the Analysis and Description of the Data}

While pipelines are fixed structures, they are not constrained within a particular geographic area like most entities subject to environmental and safety regulations. While many pipeline are relatively short, there are also operators that have thousands of miles of pipeline crossing numerous state borders. Federal and state regulators do divide pipelines into 'inspection units'. For operators with short pipelines, the entire company may constitute one inspection unit while larger operators may be divided based on operating areas (e.g., cities or metropolitan areas) or company organization (e.g., all elements

2 See Gray and Shimshack [10] for a comprehensive survey of the empirical literature on environmental monitoring and enforcement. 
reporting to a single vice president). Unfortunately, data on pipeline performance and enforcement is not available at the inspection-unit level. Thus this analysis focuses on the aggregate performance of individual pipeline operators, rather than the performance of a particular section of a pipeline. This analysis is most analogous to firm-level studies of compliance and environmental performance, such as Khanna and Anton [19] and Thornton, Gunningham, and Kagan [20], although it is based on data reported to the federal government rather than data collected through a voluntary survey.

As discussed earlier, there are 2,705 regulated pipeline operators in the U.S, over two-thirds of who operate less than 10 miles of pipeline. This analysis focuses on the 344 operators that operate 100 miles or more of pipeline. These operators represent over $90 \%$ of all pipeline incidents that occurred between 2006 and 2011 and $80 \%$ of all federal inspections during that same time frame. OPS defines an incident as any event that results in a death or personal injury necessitating in-patient hospitalization; an explosion or unintentional fire; any event that results in property damage of $\$ 50,000$ or more (excluding cost of material lost); any event that results in unintentional loss of five gallons or more of hazardous liquid or carbon dioxide or three million cubic feet of gas; any emergency that results in an emergency shutdown of a facility; or any other event that is significant in the judgment of the operator.

The Pipeline and Hazardous Materials Safety Administration (PHMSA) provides data on the performance of pipeline operators starting in $2006 .{ }^{3}$ The performance measures include the total number of reported incidents, fatalities, and injuries each year; the total dollar amount of property damage reported each year; and the reported total

${ }^{3}$ The OPS is an office within the PHMSA. 
barrels of product spilled and the net barrels of product lost each year. While these data are self-reported, the civil penalties for not reporting an incident within 30 days can be up to \$1 million dollars and any individual that "willfully and knowingly violates" the requirements can face a criminal fine of up to $\$ 25,000$ and be imprisoned for up to five years. Additionally, many of the pipeline incidents directly affect or involve third parties, making it much less likely that operators could under-report those incidents. For example, almost three-quarters of the pipeline fatalities and three-quarters of the pipeline injuries reported during the 2008 to 2012 period involved third-party (non-industry) individuals. ${ }^{4}$

Table 1 presents a summary of the performance measures for 2010 for the operators in this study. First, note that for all of these measures, the majority of operators have nothing to report. The most widely reported measure is property damage, followed closely by incidents. Property damage is reported more often than incidents because events that cause less than $\$ 50,000$ in property damage are not considered incidents if they do not also result in fatalities, significant injuries, or sufficient loss of material. Given the relatively small number of operators that report in a given year, I aggregate performance data for 2009 and 2010 to increase the number of operators reporting. The mean and standard deviations for the aggregated data are presented in Table 2 which includes summary statistics for all variables used in the analysis. Note that the summary statistics are for all operators in the study, not just those reporting.

One of the principal challenges that can arise when trying to estimate the effectiveness of inspections and enforcement on performance is that of endogeneity or reverse causality, which can occur if there are omitted explanatory variables or the

4 See "Consequences to the Public and the Pipeline Industry" available at http://primis.phmsa.dot.gov/comm/reports/safety/cpi.html (last accessed July 11, 2013). 
compliance and enforcement decisions are made simultaneously. With respect to the omitted variables concern, due to data limitations the analysis may not include some factors that affect both the operator's environmental performance as well as the regulator's decision to conduct inspections. For example, significant flooding in an area may cause pipelines to rupture, but might also bring increased inspections to that area. With respect to the simultaneity concern, contemporaneous inspections may be endogenous to the number of incidents reported if inspections serve as a significant mechanism through which incidents are discovered or reported. Similarly, the number of enforcement cases and amount of proposed penalties in a particular period are likely to depend on the number of incidents and fatalities that occur in that same time period. To address this concern I lag the enforcement variables, which may be endogenous, and I also include the lagged dependent variable as an explanatory variable. Ideally I would also use an instrumental variables approach to control for endogeneity, but due to the limited information available about pipeline inspections and enforcement, I have not been able to find any valid instruments to use for such an approach.

The first set of explanatory variables presented in Table 2 depicts the level of federal and state enforcement for each operator in the analysis. The three federal measures - Federal Inspections06-08, Federal Cases Initiated06-08, and Federal Proposed Penalties06-08 each capture a different aspect of the specific deterrence a particular operator faces from federal sources, as they capture the level of inspections and enforcement for that specific operator during the 2006-2008 period. In contrast, the three state measures are all general deterrence measures that capture the general level of enforcement for the states through which the operator's pipelines run. The state measures are general measures rather than 
specific measures because the state data is only available at the aggregate level. For each state I first normalize the relevant variable $X$-State Inspections $06-08$, State Actions Taken 06 08, and State Assessed Penalties $06-08$ - by the total number of pipeline miles in the state. For each operator $i$, I then use data on the total number of pipeline miles the operator has in each state $j$ to construct each measure $X$ for that operator as follows:

$$
\sum_{j} \text { Miles }_{i j} * \frac{X_{j}}{\text { Miles }_{j}}
$$

The state inspection data was obtained through a Freedom of Information Act request, while the data on state compliance actions taken and penalties assessed was collected from the PHMSA website.

The next set of explanatory variables measures past reported performance (i.e., reported performance during the 2006-2008 period) and, due to limited data capturing operator characteristics, is used in conjunction with the analogous 2009-2010 variables to control for differences in underlying propensities to comply with pipeline regulations. Additionally, Sosa and Alvarez-Ramirez [7] show that the number of previous incidents positively correlates with future incidents. One of the operator characteristics that I can control for is the Miles of pipeline the operator owns. Both Miles and Miles Squared are included in the analysis to account for the fact that longer pipelines have more opportunities for failure. I also include the dummy variable Intrastate that indicates whether the pipeline is confined within a single state. While OPS concentrates enforcement efforts on interstate pipelines, federal inspectors do inspect intrastate pipelines on occasion. Number of States measures the number of states through which the pipeline passes, while the four regional dummies capture the Census region(s) in which the 
operator operates. Finally there are four dummy variables that capture the type of pipelines and the materials transported in the pipelines that each operator owns:

- Gas Gathering lines collect and move natural gas from wells or offshore vessels to storage or processing facilities.

- Gas Transmission lines transport natural gas from gathering lines or storage facilities to distribution centers, storage facilities, power plants, and industrial customers and municipalities. These are generally the longest type of gas lines and are usually underground.

- Gas Distribution lines move natural gas to industrial customers and residences and are usually located in underground utility easements along streets.

- Hazardous Liquid lines transport petroleum products and other hazardous liquids, usually over long distances and underground.

\section{Results and Policy Implications}

Table 3 presents the results of the ordinary least squares regression for each of the 2009 to 2010 reported performance variables. In the first column, the dependent variable is the number of incidents reported in 2009 and 2010. Looking first at the federal enforcement variables, notice that none of the coefficients are negative. Moreover, the positive coefficients for Federal Cases Initiated $06-08$ and Federal Proposed Penalties $06-08$ are

both significant - the opposite of what one would expect if past enforcement actions served to increase overall environmental performance. One possible explanation could be that it takes a long period of time for operators to change their performance; thus, operators with past incidents that warranted significant enforcement may be more likely to continue to 
report a high number of incidents. To control for this, I did include past incidents (Dependent Variable $06-08$ ) in the regression, which also has a positive and significant sign, but it may not be a perfect control. The results for the state enforcement variables are more consistent with expectations. Both State Inspections $06-08$ and State Penalties Assessed $06-08$ have negative coefficients, and the former is significant.

Looking across the other performance variables, it is interesting to note that the results for the enforcement measures are quite mixed. Federal Inspections $06-08$ and Federal Proposed Penalties06-08, always have positive coefficients, and those coefficient are significant in a number of the regressions. On the other hand, Federal Cases Initiated $06-08$ has a negative coefficient for all but the Incidents regression, and the coefficient is significant for all but the Fatalities regression. The state enforcement results are also mixed. In contrast to the negative relationship between federal cases and performance - or, more correctly, non-performance - all of the significant coefficients on State Actions Taken $_{06-08}$ are positive. Similarly, while federal proposed penalties are positively related to non-performance in most of the regressions, all of the coefficients on State Penalties Assessed $_{06-08}$ are negative. State Inspections ${ }_{06-08}$ has a negative and significant coefficient only in the Incidents regression, but has a positive and significant coefficient in the Net Barrels Lost regression. While one might expect that some of this inconsistency could be caused by multicollinearity among the federal and state enforcement variables, the variables are not as highly correlated as one might expect. Only three pairs of variables have a correlation coefficient above 0.6: Federal Inspections and Federal Cases Initiated have a correlation coefficient of 0.67; Federal Inspections and State Inspections have a 
correlation coefficient of 0.70 , and State Inspections and State Actions Taken have a correlation coefficient of 0.76 .

Clearly these results paint a very mixed picture of the effectiveness of federal and state enforcement efforts at deterring poor environmental performance at pipelines. In particular, in terms of predicting the success of the Pipeline Safety, Regulatory Certainty, and Job Creation Act in increasing pipeline safety, there is no evidence that indicates federal inspections or fines increase environmental performance, although there is some evidence that state inspections and penalties can have such an effect. ${ }^{5}$ While Federal Cases Initiated $06-08$ does have a relatively consistent negative and significant effect on nonperformance, the Pipeline Safety, Regulatory Certainty, and Job Creation Act explicitly focuses on increased federal inspections rather than more rigorous enforcement; thus, it is not clear how the number of cases initiated will change with increased enforcement resources.

The remaining results in Table 3 provide some insight into why federal enforcement may not be particularly effective at decreasing poor environmental performance. First, observe that the coefficient on the lagged dependent variable in each regression (listed as Dependent Variable $06-08$ ) is positive and significant for four of the regressions. Thus, for overall incidents, injuries, gross barrels spilled, and net barrels lost, there is considerable persistence across time - particularly when one recalls the difference in time frames across the two variables (three years to two years). The less predictable nature of fatalities and

${ }^{5}$ One might be concerned that due to the self-reported nature of the data, some incidents are systematically going unreported in way that biases the findings of this study. Appendix A presents the results of a sensitivity analysis that suggests that under-reporting cannot explain the lack of significant negative coefficients on federal inspections. 
property damage makes intuitive sense and is consistent with the Sosa and AlvarezRamirez [7] finding that more severe incidents are unpredictable.

I had expected that the non-performance measures would all be positively related to the length of the pipeline, but interestingly Miles has the expected positive and significant coefficient only in the Incidents regression. For Fatalities, Injuries, and Property Damage, longer pipelines have fewer negative outcomes, ceteris paribus. Also, across all of the regressions the coefficient on Miles Squared is negative (although significant in only two of the six regressions). Of course, there are a number of other variables that indirectly capture the length of the pipeline, including the state enforcement variables. However, these results suggests for at least some of the performance variables, there may be important nonlinearities.

While very few of the remaining explanatory variables have a consistent effect on the performance variables, note that Gas Gathering has a significant and positive coefficient in the Fatalities, Injuries, and Property Damage regressions. Comparing the size of the three significant Gas Gathering coefficients to the mean and standard deviation for the three performance measures, note that operating a gas gathering pipeline is quantitatively a very important determinant for fatalities, injuries and property damage and may help explain why federal and state level enforcement actions are not more important deterrents for at least these types of non-performance.

Although lagging the federal enforcement variables and conditioning on prior values of the dependent variables should help to identify and estimate causal effects, as discussed in section 4 one might still be concerned that these results could be due to endogeneity. In similar situations other researchers have employed an instrumental variables approach to 
try to control for potential endogeneity, but given the limited information available about pipeline inspections and enforcement, I have not been able to find valid instruments for such an approach. As an alternative, I use Manski's partial identification approach [21, 22] to estimate plausible bounds for the causal effects of federal enforcement. As discussed in more detail in Appendix B, this partial identification approach suggests that all of the positive coefficients on the federal enforcement variables in the Incidents, Property Damage, Gross Barrels Spilled, and Net Barrels Lost regressions are plausible even if one assumes that regulators do target operators with higher levels of non-performance for enforcement actions. However, partial identification suggests that significant positive coefficients on the federal enforcement variables for the Fatalities and Injuries regressions would not be consistent with that assumption. Interestingly, I do not find any positive and significant coefficients for the federal enforcement variables in either the Fatalities or the Injuries regressions.

To provide additional insight into the mixed results presented in Table 3, I also analyzed federal inspections and enforcement as a function of past performance. Table 4 presents the results of ordinary least square regressions of Federal Inspections 09-10, Federal Cases Initiated $09-10$, and Federal Proposed Penalties $09-10$ as a function of the lagged performance measures, the lagged dependent variable, and the explanatory variables used in the performance regressions. Looking first at the results for the Federal Inspections regression, note that only Fatalities $06-08$ has a positive and significant coefficient among the performance measures, indicating that federal inspectors do target operators for inspections if there have been fatalities at the operator's pipelines in the recent past. Interestingly, the coefficient on Injuries $06-08$ is negative and significant which is not 
consistent with the idea of targeting based on past performance. This pattern shows up in both of the other regressions; that is, the coefficient on Fatalities $06-08$ is positive and significant for both Federal Cases and Federal Penalties, while the coefficient on Injuries06-08 is negative for both and significant for Federal Cases. Barrels Lost $06-08$ is also a significant determinant of Federal Cases Initiated09-10, while Incidents06-08 and Property Damage $06-08$ are significant determinants of Federal Proposed Penalties09-10.

For both Federal Inspections and Federal Cases there is some persistence across the two periods given the positive and significant coefficients on the lagged dependent variable. There are a number of possible explanations for this result. Recall that pipelines which pass through "high consequence" areas are subject to more stringent regulation and may also face more inspections. Similarly, pipelines carrying particularly hazardous materials may be inspected more often. Interestingly, there is a negative relationship between current and lagged Federal Penalties, so that facilities that faced higher penalties in the past face lower penalties currently, ceteris paribus.

Next, consider the lagged state enforcement variables. State Inspections06-08 has a positive coefficient in all three regressions, and it is significant for Federal Cases and Federal Penalties. If state inspections uncover behavior that helps federal regulators initiate enforcement proceedings, one would expect to see a positive relationship between these variables. Interestingly, the negative and significant coefficient on State Actions Takeno6-08 suggests that federal regulators may take into account state actions and hold off on their own enforcement actions against operators that have been subject to state actions in the recent past. However, the positive and significant coefficient on State Penalties Assessed $06-08$ in the Federal Cases regression is inconsistent with such an interpretation. 
Looking next at the operator characteristics variables, as expected longer pipelines face more inspections than shorter pipelines, although they are not subject to more federal cases or higher federal penalties. This finding makes sense, as inspections should depend on the potential for harm, while enforcement actions should depend on the presence of actual harm or violations. The insignificant coefficients on all of the regional dummies indicate there are not significant differences in the number of inspections based on the regions through which a pipeline runs. However, there are significant differences in the number of federal cases and penalties proposed by region, even after controlling for performance. While there are many possible explanations for these findings, they are consistent with regulators in different regions having different opinions about when cases should be initiated and how penalties should be set. Interestingly, even though the regressions in Table 3 suggest that pipeline performance depends on the type of pipeline Gas Gathering, Gas Distribution, etc. - there is no variation in federal enforcement across the different types of pipelines.

\section{Conclusion}

The goal of this paper is to provide insight into the role that federal inspections, enforcement actions, and fines have had on pipeline performance and, in particular, to examine whether the increased inspections funding and civil penalties mandated under the Pipeline Safety, Regulatory Certainty, and Job Creation Act are likely to increase pipeline safety. The results of the analysis do not provide compelling evidence that either federal inspections or civil penalties serve as particularly effective deterrents. In fact, I find that lagged federal inspections and penalties are positively associated with environmental non- 
performance, although the results have to be interpreted with some care as lagging the enforcement variables may not fully correct for omitted variables or endogeneity between enforcement and performance.

Interestingly, my analysis does find that the number of federal cases initiated against an operator does have a significant deterrent effect on many forms of nonperformance, although not for incidents in general. Thus, in theory increasing the number of federal cases would result in better environmental performance. However, the Pipeline Safety, Regulatory Certainty, and Job Creation Act focuses on increasing inspections and fines, not increasing the number of cases, although additional cases could indirectly result from the Act.

The analysis of federal inspections, enforcement cases, and proposed penalties suggests that some targeting of federal enforcement resources is based on past performance, but the results suggest that there may be room for improvement. If federal enforcement resources were better targeted, the deterrent effect of such resources might increase. The analysis also points out some variation across regions in enforcement that could indicate inefficient resource deployment. Finally, the analysis reveals interesting patterns between state and federal enforcement efforts. Additional research to better understand the relationship between such efforts could help increase our understanding of how such resources are currently coordinated and whether better coordination might increase deterrence. 
Table 1: 2010 Performance Measures for Operators with 100 or More Miles of Pipeline ( $\mathrm{N}=344)$

\begin{tabular}{|l|c|r|c|c|c|}
\hline Performance & \multirow{2}{*}{$\begin{array}{c}\text { Facilities with } \\
\text { Measure }\end{array}$} & \multicolumn{4}{|c|}{ For Facilities that Report } \\
\cline { 3 - 6 } & Nothing to Report & Mean & Std. Dev. & Minimum & Maximum \\
\hline Number of Incidents & $236(69 \%)$ & 3.96 & 4.75 & 1 & 26 \\
\hline Number of Fatalities & $340(99 \%)$ & 2.75 & 3.50 & 1 & 8 \\
\hline Number of Injuries & $337(98 \%)$ & 9.14 & 18.57 & 1 & 51 \\
\hline $\begin{array}{l}\text { Property Damage } \\
\text { (in Million \$s) }\end{array}$ & $235(68 \%)$ & 10.40 & 67.50 & 0.003 & 601 \\
\hline $\begin{array}{l}\text { Gross Barrels Spilled } \\
\text { thousands) }\end{array}$ & $285(83 \%)$ & 2.91 & 10.21 & 0.002 & 70.19 \\
\hline $\begin{array}{l}\text { Net Barrels Lost } \\
\text { (thousands) }\end{array}$ & $298(87 \%)$ & 2.66 & 10.68 & 0.001 & 70.19 \\
\hline
\end{tabular}


Table 2: Summary Statistics for the Variables Used in the Analysis

\begin{tabular}{|c|c|c|c|}
\hline Variable & Description & Mean & Std. Dev. \\
\hline \multicolumn{4}{|c|}{ Performance Measures (Dependent Variables) } \\
\hline Incidents $09-10$ & $\begin{array}{l}\text { Number of incidents reported during } \\
2009-2010 \text {. }\end{array}$ & 2.51 & 6.33 \\
\hline Fatalities $09-10$ & $\begin{array}{l}\text { Number of fatalities reported during } \\
2009-2010 \text {. }\end{array}$ & 0.04 & 0.47 \\
\hline Injurieso9-10 & $\begin{array}{l}\text { Number of injuries reported during } \\
2009-2010 .\end{array}$ & 0.23 & 2.79 \\
\hline Property Damage $09-10$ & $\begin{array}{l}\text { Property damage reported during 2009- } \\
2010 \text { in million \$s. }\end{array}$ & 3.63 & 38.29 \\
\hline Barrels Spilled $_{09-10}$ & $\begin{array}{l}\text { Barrels reported spilled during 2009- } \\
2010 \text { in thousands of barrels. }\end{array}$ & 0.65 & 4.44 \\
\hline Barrels Lost ${ }_{09-10}$ & $\begin{array}{l}\text { Net barrels reported lost during 2009- } \\
2010 \text { in thousands of barrels. }\end{array}$ & 0.45 & 4.04 \\
\hline \multicolumn{4}{|c|}{ Enforcement Measures } \\
\hline $\begin{array}{l}\text { Federal } \\
\text { Inspections } 06-08\end{array}$ & $\begin{array}{l}\text { Number of federal inspections at the } \\
\text { operator's facilities during 2006-2008 } \\
\text { (100's). }\end{array}$ & 0.33 & 0.73 \\
\hline $\begin{array}{l}\text { Federal Cases } \\
\text { Initiated }_{06-08}\end{array}$ & $\begin{array}{l}\text { Number of federal enforcement cases } \\
\text { initiated against operator during 2006- } \\
2008 \text {. }\end{array}$ & 1.24 & 2.40 \\
\hline $\begin{array}{l}\text { Federal Proposed } \\
\text { Penalties }_{06-08}\end{array}$ & $\begin{array}{l}\text { Proposed Penalties on the operator } \\
\text { during 2006-2008 (million \$'s). }\end{array}$ & 0.39 & 0.25 \\
\hline State Inspections $06-08$ & $\begin{array}{l}\text { Weighted sum of total state inspections } \\
\text { during } 2006-2008\left(100^{\prime} \mathrm{s}\right) .\end{array}$ & 0.79 & 1.58 \\
\hline $\begin{array}{l}\text { State Actions } \\
\text { Taken } 06-08\end{array}$ & $\begin{array}{l}\text { Weighted sum of total state actions taken } \\
\text { during 2006-2008. }\end{array}$ & 8.87 & 18.90 \\
\hline $\begin{array}{l}\text { State Penalties } \\
\text { Assessed } 06-08\end{array}$ & $\begin{array}{l}\text { Weighted sum of total state penalties } \\
\text { assessed during } 2006-2008 \text { ( } \$ 100,000 \text { 's). }\end{array}$ & 0.07 & 0.28 \\
\hline \multicolumn{4}{|c|}{ Past Performance Measures } \\
\hline Incidents $06-08$ & $\begin{array}{l}\text { Number of incidents reported during } \\
2006-2008 \text {. }\end{array}$ & 3.93 & 9.75 \\
\hline Fatalities $06-08$ & $\begin{array}{l}\text { Number of fatalities reported during } \\
2006-2008 \text {. }\end{array}$ & 0.03 & 0.20 \\
\hline Injuries $06-08$ & $\begin{array}{l}\text { Number of injuries reported during } \\
2009-2010 \text {. }\end{array}$ & 0.07 & 0.46 \\
\hline Property Damage $06-08$ & $\begin{array}{l}\text { Property damage reported during 2006- } \\
2008 \text { in million \$s. }\end{array}$ & 2.06 & 8.63 \\
\hline Barrels Spilled $06-08$ & $\begin{array}{l}\text { Barrels spilled during 2006-2008 in } \\
\text { thousands of barrels. }\end{array}$ & 0.92 & 5.04 \\
\hline Barrels Lost $06-08$ & $\begin{array}{l}\text { Net barrels lost during 2006-2008 in } \\
\text { thousands of barrels. }\end{array}$ & 0.52 & 3.62 \\
\hline
\end{tabular}




\begin{tabular}{|c|c|c|c|}
\hline Variable & Description & Mean & Std. Dev. \\
\hline \multicolumn{4}{|c|}{ Other Operator Characteristics } \\
\hline Miles & Miles of pipeline, in thousands & 1.42 & 2.60 \\
\hline Intrastate & $=1$ if all operations in the same state & 0.39 & 0.49 \\
\hline Number of States & $\begin{array}{l}\text { Number of states through which the } \\
\text { operator's pipeline passes. }\end{array}$ & 3.17 & 3.28 \\
\hline Region 1 & $\begin{array}{l}=1 \text { if any pipeline is located in the } \\
\text { Northeast. }\end{array}$ & 0.11 & 0.32 \\
\hline Region 2 & $\begin{array}{l}=1 \text { if any pipeline is located in the } \\
\text { Midwest. }\end{array}$ & 0.38 & 0.49 \\
\hline Region 3 & $=1$ if any pipeline is located in the South. & 0.63 & 0.48 \\
\hline Region 4 & $=1$ if any pipeline is located in the West. & 0.29 & 0.45 \\
\hline Gas Gathering & $\begin{array}{l}=1 \text { if operations include natural gas } \\
\text { gathering. }\end{array}$ & 0.24 & 0.43 \\
\hline Gas Transmission & $\begin{array}{l}=1 \text { if operations include natural gas } \\
\text { transmission. }\end{array}$ & 0.75 & 0.44 \\
\hline Gas Distribution & $\begin{array}{l}=1 \text { if operations include natural gas } \\
\text { distribution. }\end{array}$ & 0.26 & 0.44 \\
\hline Hazardous Liquid & $\begin{array}{l}=1 \text { if operations include hazardous liquid } \\
\text { transmission. }\end{array}$ & 0.44 & 0.50 \\
\hline
\end{tabular}


Table 3: OLS Results for Various Measures of Environmental Performance

\begin{tabular}{|c|c|c|c|}
\hline & Incidents & Fatalities & Injuries \\
\hline Federal Inspections $06-08$ & $\begin{array}{c}0.33 \\
(0.34) \\
\end{array}$ & $\begin{array}{c}0.04 \\
(0.06) \\
\end{array}$ & $\begin{array}{c}0.43 \\
(0.32)\end{array}$ \\
\hline Federal Cases Initiated $06-08$ & $\begin{array}{r}0.17^{*} \\
(0.09)\end{array}$ & $\begin{array}{l}-0.02 \\
(0.01)\end{array}$ & $\begin{array}{l}-0.18^{* *} \\
(0.08)\end{array}$ \\
\hline Federal Proposed Penalties $06-08$ & $\begin{array}{l}1.32^{* *} \\
(0.64)\end{array}$ & $\begin{array}{c}0.02 \\
(0.11)\end{array}$ & $\begin{array}{c}0.70 \\
(0.58)\end{array}$ \\
\hline State Inspections ${ }_{06-08}$ & $\begin{array}{l}-0.68^{* *} \\
(0.34)\end{array}$ & $\begin{array}{l}-0.05 \\
(0.05)\end{array}$ & $\begin{array}{c}0.003 \\
(0.31)\end{array}$ \\
\hline State Actions Taken $06-08$ & $\begin{array}{c}0.01 \\
(0.02)\end{array}$ & $\begin{array}{c}0.02^{* *} \\
(0.002)\end{array}$ & $\begin{array}{c}0.15^{* *} \\
(0.01)\end{array}$ \\
\hline State Penalties Assessed $06-08$ & $\begin{array}{l}-0.73 \\
(0.59)\end{array}$ & $\begin{array}{l}-0.12 \\
(0.10)\end{array}$ & $\begin{array}{l}-0.65 \\
(0.54)\end{array}$ \\
\hline Dependent Variable $\dagger_{06-08}$ & $\begin{array}{c}0.47^{* *} \\
(0.02)\end{array}$ & $\begin{array}{c}0.13 \\
(0.13)\end{array}$ & $\begin{array}{c}0.58^{* *} \\
(0.30)\end{array}$ \\
\hline Miles & $\begin{array}{c}0.75^{* *} \\
(0.30)\end{array}$ & $\begin{array}{l}-0.08^{*} \\
(0.05)\end{array}$ & $\begin{array}{l}-0.63^{* *} \\
(0.27)\end{array}$ \\
\hline Miles Squared & $\begin{array}{l}-0.02^{* *} \\
(0.01)\end{array}$ & $\begin{array}{l}-0.002 \\
(0.002)\end{array}$ & $\begin{array}{l}-0.01 \\
(0.01)\end{array}$ \\
\hline Intrastate & $\begin{array}{c}0.37 \\
(0.36)\end{array}$ & $\begin{array}{l}-0.01 \\
(0.06)\end{array}$ & $\begin{array}{l}-0.15 \\
(0.32)\end{array}$ \\
\hline Number of States & $\begin{array}{c}0.31^{* *} \\
(0.10)\end{array}$ & $\begin{array}{c}0.02 \\
(0.02)\end{array}$ & $\begin{array}{c}0.04 \\
(0.09)\end{array}$ \\
\hline Region 1 & $\begin{array}{c}0.20 \\
(0.58)\end{array}$ & $\begin{array}{c}0.04 \\
(0.09)\end{array}$ & $\begin{array}{l}-0.23 \\
(0.53)\end{array}$ \\
\hline Region 2 & $\begin{array}{l}-0.51 \\
(0.41)\end{array}$ & $\begin{array}{c}0.03 \\
(0.06)\end{array}$ & $\begin{array}{c}0.22 \\
(0.37)\end{array}$ \\
\hline Region 3 & $\begin{array}{l}-0.52 \\
(0.42)\end{array}$ & $\begin{array}{l}-0.10 \\
(0.07)\end{array}$ & $\begin{array}{l}-0.58 \\
(0.38)\end{array}$ \\
\hline Region 4 & $\begin{array}{l}-1.12^{* *} \\
(0.42)\end{array}$ & $\begin{array}{l}-0.002 \\
(0.07)\end{array}$ & $\begin{array}{c}0.21 \\
(0.39)\end{array}$ \\
\hline Gas Gathering & $\begin{array}{c}0.04 \\
(0.36)\end{array}$ & $\begin{array}{l}0.13^{* *} \\
(0.06)\end{array}$ & $\begin{array}{c}0.82^{* *} \\
(0.33)\end{array}$ \\
\hline Gas Transmission & $\begin{array}{l}-0.71^{*} \\
(0.40)\end{array}$ & $\begin{array}{l}-0.08 \\
(0.07)\end{array}$ & $\begin{array}{l}-0.31 \\
(0.37)\end{array}$ \\
\hline Gas Distribution & $\begin{array}{c}0.56 \\
(0.40)\end{array}$ & $\begin{array}{c}0.07 \\
(0.06)\end{array}$ & $\begin{array}{c}0.43 \\
(0.36)\end{array}$ \\
\hline Hazardous Liquid & $\begin{array}{c}0.51 \\
(0.39)\end{array}$ & $\begin{array}{l}-0.07 \\
(0.06)\end{array}$ & $\begin{array}{l}-0.39 \\
(0.36)\end{array}$ \\
\hline Constant & $\begin{array}{l}-0.18 \\
(0.61)\end{array}$ & $\begin{array}{c}0.04 \\
(0.10)\end{array}$ & $\begin{array}{c}0.26 \\
(0.55)\end{array}$ \\
\hline R-squared & 0.84 & 0.27 & 0.33 \\
\hline
\end{tabular}

Sig. at the 5\% level; *Sig. at the 10\% level.; † Equal to the dep. var. for the period 2006-2008. 
Table 3, Continued

\begin{tabular}{|c|c|c|c|}
\hline & $\begin{array}{c}\text { Property } \\
\text { Damage }\end{array}$ & $\begin{array}{c}\text { Gross Barrels } \\
\text { Spilled }\end{array}$ & $\begin{array}{c}\text { Net Barrels } \\
\text { Lost }\end{array}$ \\
\hline $\begin{array}{l}\text { Federal } \\
\text { Inspections } 06-08\end{array}$ & $\begin{array}{c}0.08^{*} \\
(0.04)\end{array}$ & $\begin{array}{c}0.55 \\
(0.45)\end{array}$ & $\begin{array}{r}0.42^{*} \\
(0.25)\end{array}$ \\
\hline Federal Cases Initiated $06-08$ & $\begin{array}{l}-2.04^{*} \\
(1.06)\end{array}$ & $\begin{array}{l}-0.39 * * \\
(0.12)\end{array}$ & $\begin{array}{l}-0.51^{* *} \\
(0.07)\end{array}$ \\
\hline Federal Proposed Penalties $06-08$ & $\begin{array}{l}77.80^{* *} \\
(7.76)\end{array}$ & $\begin{array}{l}3.93^{* *} \\
(0.82)\end{array}$ & $\begin{array}{l}1.07^{* *} \\
(0.46)\end{array}$ \\
\hline State Inspections $s_{06-08}$ & $\begin{array}{c}2.55 \\
(4.22)\end{array}$ & $\begin{array}{c}0.41 \\
(0.45)\end{array}$ & $\begin{array}{l}0.66^{* *} \\
(0.25)\end{array}$ \\
\hline $\begin{array}{l}\text { State Actions } \\
\text { Taken } 06-08\end{array}$ & $\begin{array}{l}1.37^{* *} \\
(0.20)\end{array}$ & $\begin{array}{r}0.004 \\
(0.02) \\
\end{array}$ & $\begin{array}{l}-0.01 \\
(0.01)\end{array}$ \\
\hline State Penalties Assessed ${ }_{06-08}$ & $\begin{array}{r}-14.17^{*} \\
(7.25)\end{array}$ & $\begin{array}{l}-0.33 \\
(0.76)\end{array}$ & $\begin{array}{c}0.38 \\
(0.42)\end{array}$ \\
\hline Dependent Variable $\dagger_{06-08}$ & $\begin{array}{c}0.22 \\
(0.25)\end{array}$ & $\begin{array}{l}0.62^{* *} \\
(0.04)\end{array}$ & $\begin{array}{l}1.11^{* *} \\
(0.03)\end{array}$ \\
\hline Miles & $\begin{array}{l}-7.73^{*} \\
(3.69)\end{array}$ & $\begin{array}{l}-0.19 \\
(0.39)\end{array}$ & $\begin{array}{l}-0.08 \\
(0.21)\end{array}$ \\
\hline Miles Squared & $\begin{array}{l}-0.19 \\
(0.13)\end{array}$ & $\begin{array}{l}-0.01 \\
(0.01)\end{array}$ & $\begin{array}{l}-0.02^{* *} \\
(0.01)\end{array}$ \\
\hline Intrastate & $\begin{array}{l}-3.88 \\
(4.40)\end{array}$ & $\begin{array}{l}-0.60 \\
(0.46)\end{array}$ & $\begin{array}{l}-0.31 \\
(0.26)\end{array}$ \\
\hline Number of States & $\begin{array}{c}0.75 \\
(1.22)\end{array}$ & $\begin{array}{l}-0.05 \\
(0.12)\end{array}$ & $\begin{array}{l}-0.12^{*} \\
(0.07)\end{array}$ \\
\hline Region 1 & $\begin{array}{c}6.71 \\
(7.14)\end{array}$ & $\begin{array}{l}-0.35 \\
(0.76)\end{array}$ & $\begin{array}{l}-0.56 \\
(0.42)\end{array}$ \\
\hline Region 2 & $\begin{array}{c}0.02 \\
(4.94) \\
\end{array}$ & $\begin{array}{l}-0.59 \\
(0.52)\end{array}$ & $\begin{array}{c}0.12 \\
(0.29)\end{array}$ \\
\hline Region 3 & $\begin{array}{c}-13.02^{* *} \\
(5.11)\end{array}$ & $\begin{array}{l}-0.65 \\
(0.54)\end{array}$ & $\begin{array}{l}-0.08 \\
(0.30)\end{array}$ \\
\hline Region 4 & $\begin{array}{l}-8.49^{*} \\
(5.14)\end{array}$ & $\begin{array}{l}-0.60 \\
(0.55)\end{array}$ & $\begin{array}{c}0.11 \\
(0.30)\end{array}$ \\
\hline Gas Gathering & $\begin{array}{r}8.58^{*} \\
(4.45)\end{array}$ & $\begin{array}{l}-0.13 \\
(0.47)\end{array}$ & $\begin{array}{l}-0.04 \\
(0.26)\end{array}$ \\
\hline Gas Transmission & $\begin{array}{c}-12.00^{* *} \\
(4.98)\end{array}$ & $\begin{array}{c}0.52 \\
(0.53)\end{array}$ & $\begin{array}{c}0.31 \\
(0.29)\end{array}$ \\
\hline Gas Distribution & $\begin{array}{c}3.05 \\
(4.85)\end{array}$ & $\begin{array}{l}-0.56 \\
(0.51)\end{array}$ & $\begin{array}{l}-0.76^{* *} \\
(0.28)\end{array}$ \\
\hline Hazardous Liquid & $\begin{array}{l}-5.46 \\
(4.78)\end{array}$ & $\begin{array}{c}0.51 \\
(0.51)\end{array}$ & $\begin{array}{c}0.16 \\
(0.28)\end{array}$ \\
\hline Constant & $\begin{array}{l}17.31^{* *} \\
(7.31)\end{array}$ & $\begin{array}{c}0.97 \\
(0.77)\end{array}$ & $\begin{array}{c}0.58 \\
(0.42)\end{array}$ \\
\hline R-squared & 0.36 & 0.46 & 0.80 \\
\hline
\end{tabular}

${ }^{* *}$ Sig. at the 5\% level; *Sig. at the $10 \%$ level.; † Equal to the dep. var. for the period 2006-2008. 
Table 4: OLS Results for Various Measures of Federal Enforcement, 2009-2010

\begin{tabular}{|c|c|c|c|}
\hline & $\begin{array}{c}\text { Federal } \\
\text { Inspections }\end{array}$ & $\begin{array}{c}\text { Federal Cases } \\
\text { Initiated }\end{array}$ & $\begin{array}{c}\text { Federal Proposed } \\
\text { Penalties }\end{array}$ \\
\hline Incidents $06-08$ & $\begin{array}{c}0.25 \\
(0.22)\end{array}$ & $\begin{array}{c}0.003 \\
(0.008)\end{array}$ & $\begin{array}{c}0.002^{* *} \\
(0.001)\end{array}$ \\
\hline Fatalities $06-08$ & $\begin{array}{l}43.14^{* *} \\
(8.20)\end{array}$ & $\begin{array}{l}1.02^{*} \\
(0.31)\end{array}$ & $\begin{array}{c}0.08^{*} \\
(0.05)\end{array}$ \\
\hline Injuries $_{06-08}$ & $\begin{array}{c}-13.31^{* *} \\
(3.50)\end{array}$ & $\begin{array}{l}-0.32^{* *} \\
(0.13)\end{array}$ & $\begin{array}{l}-0.02 \\
(0.02)\end{array}$ \\
\hline Property Damage $06-08$ & $\begin{array}{c}0.10 \\
(0.21)\end{array}$ & $\begin{array}{l}-0.01 \\
(0.01)\end{array}$ & $\begin{array}{c}0.008^{* *} \\
(0.001)\end{array}$ \\
\hline Barrels Spilled $_{06-08}$ & $\begin{array}{c}0.05 \\
(0.47)\end{array}$ & $\begin{array}{l}-0.01 \\
(0.02)\end{array}$ & $\begin{array}{c}0.001 \\
(0.002)\end{array}$ \\
\hline Barrels Lost $06-08$ & $\begin{array}{l}-0.07 \\
(0.65)\end{array}$ & $\begin{array}{l}0.06^{* *} \\
(0.02)\end{array}$ & $\begin{array}{l}-0.001 \\
(0.003)\end{array}$ \\
\hline Dependent Variable $\dagger_{06-08}$ & $\begin{array}{l}0.18^{* *} \\
(0.03)\end{array}$ & $\begin{array}{l}0.21^{* *} \\
(0.03)\end{array}$ & $\begin{array}{l}-0.06^{*} \\
(0.03)\end{array}$ \\
\hline State Inspections $06-08$ & $\begin{array}{c}0.02 \\
(0.03)\end{array}$ & $\begin{array}{c}0.006^{* *} \\
(0.001)\end{array}$ & $\begin{array}{l}0.00002^{* *} \\
(0.0001)\end{array}$ \\
\hline $\begin{array}{l}\text { State Actions } \\
\text { Taken }_{06-08}\end{array}$ & $\begin{array}{l}-0.26^{*} \\
(0.16)\end{array}$ & $\begin{array}{l}-0.12^{* *} \\
(0.01)\end{array}$ & $\begin{array}{l}-0.0013^{*} \\
(0.0007)\end{array}$ \\
\hline State Penalties Assessed ${ }_{06-08}$ & $\begin{array}{c}3.78 \\
(5.52)\end{array}$ & $\begin{array}{r}0.37^{*} \\
(0.21)\end{array}$ & $\begin{array}{c}0.02 \\
(0.02)\end{array}$ \\
\hline Miles & $\begin{array}{l}6.03^{* *} \\
(2.84)\end{array}$ & $\begin{array}{l}-0.15 \\
(0.11)\end{array}$ & $\begin{array}{c}0.016 \\
(0.013)\end{array}$ \\
\hline Miles Squared & $\begin{array}{l}-0.18^{*} \\
(0.11)\end{array}$ & $\begin{array}{l}-0.0003 \\
(0.004)\end{array}$ & $\begin{array}{l}-0.0011^{* *} \\
(0.0005)\end{array}$ \\
\hline Intrastate & $\begin{array}{l}-3.28 \\
(3.37)\end{array}$ & $\begin{array}{l}0.27^{* *} \\
(0.13)\end{array}$ & $\begin{array}{c}0.01 \\
(0.01)\end{array}$ \\
\hline Number of States & $\begin{array}{c}0.62 \\
(0.94)\end{array}$ & $\begin{array}{l}0.08^{* *} \\
(0.03)\end{array}$ & $\begin{array}{c}0.004 \\
(0.005)\end{array}$ \\
\hline Region 1 & $\begin{array}{c}1.56 \\
(5.42)\end{array}$ & $\begin{array}{l}0.44^{* *} \\
(0.21)\end{array}$ & $\begin{array}{l}0.10^{* *} \\
(0.03)\end{array}$ \\
\hline Region 2 & $\begin{array}{l}-2.42 \\
(3.79)\end{array}$ & $\begin{array}{r}0.28^{*} \\
(0.14)\end{array}$ & $\begin{array}{c}0.01 \\
(0.02)\end{array}$ \\
\hline Region 3 & $\begin{array}{l}-1.90 \\
(3.91)\end{array}$ & $\begin{array}{c}0.08 \\
(0.15)\end{array}$ & $\begin{array}{c}0.02 \\
(0.02)\end{array}$ \\
\hline Region 4 & $\begin{array}{l}-0.04 \\
(3.92)\end{array}$ & $\begin{array}{l}0.34^{* *} \\
(0.15)\end{array}$ & $\begin{array}{r}0.03^{*} \\
(0.02)\end{array}$ \\
\hline
\end{tabular}

${ }^{* *}$ Signif. at the $5 \%$ level; *Signif. at the $10 \%$ level; † Equal to variable at the top of the column for 2006-08 


\section{Table 4, Con't}

\begin{tabular}{|l|c|c|c|}
\hline & $\begin{array}{c}\text { Federal } \\
\text { Inspections }\end{array}$ & $\begin{array}{c}\text { Federal Cases } \\
\text { Initiated }\end{array}$ & $\begin{array}{c}\text { Federal Proposed } \\
\text { Penalties }\end{array}$ \\
\hline Gas Gathering & -2.18 & 0.03 & 0.003 \\
& $(3.36)$ & $(0.13)$ & $(0.016)$ \\
\hline Gas Transmission & -0.43 & 0.05 & 0.026 \\
& $(3.85)$ & $(0.15)$ & $(0.018)$ \\
\hline Gas Distribution & -2.73 & -0.09 & 0.005 \\
& $(3.70)$ & $(0.14)$ & $(0.018)$ \\
\hline Hazardous Liquid & 0.66 & 0.17 & 0.026 \\
& $(3.66)$ & $(0.14)$ & $(0.018)$ \\
\hline Constant & 3.43 & $-0.52^{* *}$ & $-0.84^{* *}$ \\
& $(5.67)$ & $(0.21)$ & $0.27)$ \\
\hline R-squared & 0.59 & 0.63 & 0.43 \\
\hline
\end{tabular}

**Signif. at the 5\% level; *Signif. at the $10 \%$ level; $†$ Equal to variable at the top of the column for 2006-08. 


\section{Appendix A: Sensitivity Analysis for Self-Reported Performance Data}

If non-performance is systematically under-reported by operators that are not subject to federal enforcement, the results in Table 3 would be biased upward. To investigate whether under-reporting could provide an explanation for the positive and/or insignificant coefficients on the federal enforcement variables in the regressions presented in Table 3, I conducted the following experiment to see how badly under-reported the performance data would have to be to estimate negative and significant coefficients for the federal enforcement measures.

The experiment is based on the conjecture that operators accurately self-report if they are or have recently been inspected but may choose to under-report if they are not inspected regularly. Since the performance data used in the Table 3 regressions cover the 2009-2010 period, I assume that operators that are subject to federal inspections during 2009 and 2010 are accurately reporting their performance but that operators that are not subject to federal inspections during that period may be under-reporting. This assumption is consistent with the mean values of the performance variables for the two groups. As shown in Table A1 the mean value of all of the performance measures except Injuriesog-10 is less for the non-inspected group than for the inspected group, and all of the differences are statistically significant at the $5 \%$ level.

For those operators that were not inspected by the OPS during 2009-2010, I constructed "adjusted" performance variables where the adjusted variable is equal to the self-reported performance variable plus one standard deviation (calculated over the entire sample of 344 operators). For operators that were inspected by OPS, the adjusted variable is equal to the self-reported performance variable. I then ran the Table 3 regressions using 
the adjusted performance measures. Table A2 shows the coefficients and standard errors for the three federal enforcement variables for these adjusted regressions. Note that these results do not change the overall conclusions from Table 3 . As shown by the insignificant coefficient on Federal Inspections $06-08$ in all of the six of the regressions, there is no evidence that federal inspections improve operator performance, even with these adjustments for potential under-reporting. With the adjustments, the coefficient on Federal Cases Initiated $_{06-08}$ does become significant in the Fatalities regression, which is consistent with the study's finding that initiating federal cases can increase environmental performance. With respect to Federal Penalties Proposed $06-08$, the only qualitative difference for the adjusted regressions is that the coefficient is no longer significant in the Incidents regression.

Even if I adjust the performance variables for the operators that are not inspected by the OPS during 2009-2010 by adding 4 times the standard deviation to the initial level of performance, I cannot overturn the inspection result - the coefficients on Federal Inspections $06-08$ remain insignificant in all six regressions. However, for this extreme adjustment the coefficient on Federal Cases Initiated $06-08$ does become negative and significant in the Injuries regression as well. 
Table A1: 2009-2010 Performance Measures

\begin{tabular}{|c|c|c|c|c|c|c|}
\hline \multirow[b]{2}{*}{ Performance Measure } & \multicolumn{2}{|c|}{$\begin{array}{c}\text { All Operators } \\
(\mathrm{N}=344)\end{array}$} & \multicolumn{2}{|c|}{$\begin{array}{c}\text { Operators } \\
\text { Inspected in } \\
2009-2010 \\
(N=147)\end{array}$} & \multicolumn{2}{|c|}{$\begin{array}{c}\text { Operators } \\
\text { Not Inspected in } \\
\mathbf{2 0 0 9 - 2 0 1 0} \\
(\mathrm{N}=197)\end{array}$} \\
\hline & Mean & Std. Dev. & Mean & Std. Dev. & Mean & Std. Dev \\
\hline Incidents $_{09-10}$ & 2.51 & 6.33 & 5.06 & 8.81 & 0.60 & 1.91 \\
\hline Fatalities $09-10$ & 0.04 & 0.42 & 0.05 & 0.30 & 0.04 & 0.57 \\
\hline Injuries $09-10$ & 0.23 & 2.79 & 0.16 & 0.76 & 0.27 & 3.63 \\
\hline Property Damage $09-10$ & 3.63 & 38.29 & 5.78 & 49.66 & 2.03 & 26.88 \\
\hline Gross Barrels Spilled $09-10$ & 0.65 & 4.44 & 1.41 & 6.70 & 0.08 & 0.56 \\
\hline Net Barrels Lost ${ }_{09-10}$ & 0.45 & 4.04 & 0.96 & 6.12 & 0.07 & 0.56 \\
\hline
\end{tabular}

Table A2: OLS Regression Results for the Federal Enforcement Variables when Adjusted 2009-2010 Performance Measures are the Dependent Variables

\begin{tabular}{|l|c|c|c|}
\hline $\begin{array}{l}\text { Adjusted Performance } \\
\text { Measure }\end{array}$ & $\begin{array}{l}\text { Federal } \\
\text { Inspections }\end{array}$ & $\begin{array}{l}\text { Fed-08 } \\
\text { Initiated 06-08 }\end{array}$ & $\begin{array}{l}\text { Federal } \\
\text { Proposed } \\
\text { Penalties 06-08 }\end{array}$ \\
\hline Incidents $09-10$ & -0.03 & -0.18 & 1.30 \\
& $(0.48)$ & $(0.12)$ & $(0.87)$ \\
\hline Fatalities $09-10$ & 0.02 & $-0.04^{* *}$ & 0.05 \\
& $(0.06)$ & $(0.02)$ & $(0.12)$ \\
\hline Injuries09-10 & 0.29 & $-0.32^{* *}$ & 0.72 \\
& $(0.34)$ & $(0.09)$ & $(0.62)$ \\
\hline Property Damage $09-10$ & 5.64 & $-4.02^{* *}$ & $78.20^{* *}$ \\
& $(4.67)$ & $(1.16)$ & $(8.52)$ \\
\hline Gross Barrels Spilled $09-10$ & 0.35 & $-0.65^{* *}$ & $4.01^{* *}$ \\
& $(0.47)$ & $(0.13)$ & $(0.86)$ \\
\hline Net Barrels Lost $09-10$ & 0.21 & $-0.72^{* *}$ & $1.08^{* *}$ \\
& $(0.30)$ & $(0.08)$ & $(0.05)$ \\
\hline
\end{tabular}




\section{Appendix B: Partial Identification of Causal Effects for Federal Enforcement Variables}

Charles Manski [20] is one of the primary contributors to the recent literature on partial identification. The partial identification approach focuses on establishing plausible values for treatment effect parameters that are consistent with the observed data under relatively weak assumptions. Using these weak assumptions, researchers can develop bounds for causal effects rather than point estimates. In this appendix I use Manski's approach to develop plausible bounds for the causal effects of federal enforcement on pipeline operator performance under minimal assumptions.

Because the basic partial identification approach developed by Manski [21] focuses on binary treatments, I created three binary treatment variables, Federally Inspected ${ }_{06-08,}$ Federal Case Initiated $06-08$, and Federal Proposed Penalty $06-08$. The objective of partial identification is then to develop bounds for the effects of each of these three treatments on the six performance variables: Mean Incidents09-10, Mean Fatalities09-10, Mean Injuries09-10, Mean Property Damage 09-10, Mean Gross Barrels Spilled ${ }_{09-10}$ and Mean Net Barrels Losto9-10.

Let $T_{i}=1$ if operator $i$ is treated and $=0$ if operator $i$ is untreated. Let $Y_{1 i}$ be the performance of operator $i$ when treated and $Y_{0 i}$ be the performance when untreated. Then the individual impact of the treatment on operator $i$ is $\Delta_{i}=Y_{1 i}-Y_{0 i}$. Of course, we cannot observe both $Y_{1 i}$ and $Y_{0 i}$ as the operator cannot be both treated and untreated. Thus to estimate the causal effect of the treatment, we estimate the average treatment effect which is equal to the difference between the expected values of $Y_{1}$ and $Y_{0}$ in the population (i.e., $\left.A T E=E\left[Y_{1}\right]-E\left[Y_{0}\right]\right)$ using observable information from different operators. If the expected average treatment effect differs across those operators that are treated and those that are untreated, then the $A T E$ is the weighted average of the average treatment effect on the 
treated and the average treatment effect on the untreated. More specifically, let $w_{1}$ equal the proportion of operators that are treated. Then

$$
A T E=w_{1}^{*} E\left[Y_{1}-Y_{0} \mid T_{i}=1\right]+\left(1-w_{1}\right)^{*} E\left[Y_{1}-Y_{0} \mid T_{i}=0\right] .
$$

As a first step, in estimating the ATE, I assume that the potential performance rates for both treated and untreated operators lie within the support observed in the data on performance from 2006 to 2010 . Under this assumption the maximum possible negative treatment effect (i.e., improvement in performance) would occur when an operator's untreated performance would be equal to the maximum value and that same operator's treated performance would be equal to $0 .{ }^{6}$ The maximum possible positive treatment effect would occur when an operator's untreated performance would be equal to 0 and that same operator's treated performance would be equal to the maximum value. Let $M$ be the maximum observed performance level. Then

$$
\left.0-M \leq E\left[Y_{1}\right]-E\left[Y_{0}\right]\right) \leq M-0 .
$$

As shown in Table B1, using the historical maximum values for each of the six performance variables provides initial bounds on the possible treatment effect, although by construction these bounds are relatively large as well as symmetric.

The next step in the partial identification approach is to further refine the bounds using the relatively weak assumption that the mean observed performance data for the treated group $\left(D_{1}\right)$ gives us an unbiased estimator of the expected performance of the treated group when treated $\left(E\left[Y_{1} \mid T_{i}=1\right]\right)$ and that the mean observed performance data for the untreated group $\left(D_{0}\right)$ gives us an unbiased estimator of the expected performance for the untreated group when untreated $\left(E\left[Y_{0} \mid T_{i}=0\right]\right)$. Recalling that the ATE is a weighted

${ }^{6}$ The nature of the performance variables rule out negative values, so 0 is the smallest possible value. 
average of the expected causal effects for the treated and untreated groups, the bounds become:

$$
\left.w_{1}^{*}\left(D_{1}-M\right)+\left(1-w_{1}\right)^{*}\left(0-D_{0}\right) \leq E\left[Y_{1}\right]-E\left[Y_{0}\right]\right) \leq w_{1}^{*}\left(D_{1}-0\right)+\left(1-w_{1}\right)^{*}\left(M-D_{0}\right) .
$$

As shown in Table B1, this relatively weak assumption substantially shrinks the bounds of the $A T E .^{7}$

Given the concern that treatment selection may be endogenous, we can further shrink the bounds by making another weak assumption: that the average performance for treated firms is weakly higher than the average performance for untreated firms both with and without treatment, or

$$
E\left[Y_{1} \mid T_{i}=1\right] \geq E\left[Y_{1} \mid T_{i}=0\right] \text { and } E\left[Y_{0} \mid T_{i}=1\right] \geq E\left[Y_{0} \mid T_{i}=0\right] . .^{8}
$$

Under this assumption the upper bound becomes

$$
w_{1}^{*}\left(D_{1}-D_{0}\right)+\left(1-w_{1}\right)^{*}\left(D_{1}-D_{0}\right)=D_{1}-D_{0},
$$

while the lower bound is unchanged. Thus if one assumes positive selection, as shown in Table B1 the bounds on the ATE for Mean Fatalities $09-10$ and Mean Injuries $09-10$ rule out any quantitatively significant positive effects while the bounds on the ATE for the remaining performance variables do allow for quantitatively significant positive effects. Comparing these results to the sign and significance of the coefficients in Table 3, partial identification suggests that all of the positive coefficients on the federal enforcement variables in the Incidents, Property Damage, Gross Barrels Spilled, and Net Barrels Lost regressions are plausible even if one assumes that regulators do target operators with higher levels of non-

7 Manski calls this the "No Assumptions" bound.

8 Manski terms this the "Monotone Treatment Selection" assumption. 
performance for enforcement actions. ${ }^{9}$ However significant positive coefficients on the federal enforcement variables for the Fatalities and Injuries regressions would not be consistent with that assumption. Interestingly, I do not find any positive and significant coefficients for the federal enforcement variables in either the Fatalities or the Injuries regressions.

${ }^{9}$ Because the regressions presented in Table 3 use continuous rather than binary federal enforcement variables, the size of the coefficients cannot be directly compared to the bounds. 
Table B1: Partial Identification Bounds on Average Treatment Effects

\begin{tabular}{|c|c|c|c|c|c|c|}
\hline & $\begin{array}{c}\text { Mean } \\
\text { Incidents }_{09-10} \\
\end{array}$ & $\begin{array}{c}\text { Mean } \\
\text { Fatalities }_{09-10} \\
\end{array}$ & $\begin{array}{c}\text { Mean } \\
\text { Injuries 09-10 } \\
\end{array}$ & $\begin{array}{c}\text { Mean Property } \\
\text { Damage }_{09-10}\end{array}$ & $\begin{array}{l}\text { Mean Gross } \\
\text { Barrels } \\
\text { Spilled }_{09-10} \\
\end{array}$ & $\begin{array}{c}\text { Mean Net } \\
\text { Barrels } \\
\text { Lost }_{09-10} \\
\end{array}$ \\
\hline Historical Maximum & {$[-28,28]$} & {$[-8,8]$} & {$[-51,51]$} & {$[-601,601]$} & {$[-70.19,70.19]$} & {$[-70.19,70.19]$} \\
\hline $\begin{array}{l}\text { Inspected }_{\text {o6-08 }} \\
\text { Observed Data } \\
\text { Positive Selection }\end{array}$ & $\begin{array}{c}{[-12.16,15.84]} \\
{[-12.16,2.06]}\end{array}$ & $\begin{array}{l}{[-3.75,4.25]} \\
{[-3.75,0.00]}\end{array}$ & $\begin{array}{c}{[-23.92,27.08]} \\
{[-23.92-0.08]}\end{array}$ & $\begin{array}{l}{[-281,320]} \\
{[-281,1.47]}\end{array}$ & $\begin{array}{c}{[-32.59,37.60]} \\
{[-32.59,0.57]}\end{array}$ & $\begin{array}{c}{[-32.67,37.52]} \\
{[-32.67,0.38]}\end{array}$ \\
\hline $\begin{array}{l}\text { Case Initiated }_{06-08} \\
\text { Observed Data } \\
\text { Positive Selection } \\
\end{array}$ & $\begin{array}{c}{[-9.75,18.25]} \\
{[-9.75,2.26]}\end{array}$ & $\begin{array}{c}{[-3,5]} \\
{[-3,0.01]}\end{array}$ & $\begin{array}{c}{[-19.17,31.83]} \\
{[-19.17,-0.04]}\end{array}$ & $\begin{array}{l}{[-225,376]} \\
{[-225,2.25]}\end{array}$ & $\begin{array}{c}{[-26.06,44.13]} \\
{[-26.06,0.73]}\end{array}$ & $\begin{array}{c}{[-26.15,44.05]} \\
{[-26.15,0.50]}\end{array}$ \\
\hline $\begin{array}{l}\text { Penalty Proposed } 06-08 \\
\text { Observed Data } \\
\text { Positive Selection }\end{array}$ & $\begin{array}{c}{[-3.96,24.04]} \\
{[-3.96,4.02]}\end{array}$ & $\begin{array}{l}{[-1.17,6.83]} \\
{[-1.17,0.03]}\end{array}$ & $\begin{array}{c}{[-7.47,43.53]} \\
{[-7.47,0.08]}\end{array}$ & $\begin{array}{l}{[-87,514]} \\
{[-87,7.02]}\end{array}$ & $\begin{array}{c}{[-10.29,59.90]} \\
{[-10.29,0.58]}\end{array}$ & $\begin{array}{c}{[-10.32,59.87]} \\
{[-10.32,0.18]}\end{array}$ \\
\hline
\end{tabular}




\section{References}

[1] Terkel, Amada. "112th Congress Set To Become Most Unproductive Since 1940s," The Huffington Post, December 28, 2012.

[2] Frosch, Dan. "Congress Passes Bill Bolstering Pipeline Safety Rules," The New York Times, December 17, 2011.

[3] May, Peter J. 1991. "Reconsidering Policy Design: Policies and Publics," Journal of Public Policy Vol. 11, No. 2, pp. 187-206.

[4] Parker, Carol M. 2004. “The Pipeline Industry Meets Grief Unimaginable: Congress Reacts with the Pipeline Safety Improvement Act of 2002" Natural Resources Journal 44:243-282.

[5] Frosch, Dan and Janet Roberts. "Pipeline Spills Put Safeguards Under Scrutiny,", The New York Times, September 9, 2011.

[6] Quarterman, Cynthia L. (Administrator, Pipeline and Hazardous Materials Safety Administration, U.S. Department of Transportation). Testimony of before the House Energy and Commerce Committee, June 16, 2011.

[7] E. Sosa and J. Alvarez-Ramirez. 2009. "Time-Correlations in the Dynamics of Hazardous Materials Pipeline Incidents," Journal of Hazardous Materials 165:1204-1209.

[8] Becker, Gary S. 1968. "Crime and Punishment: An Economic Approach." Journal of Political Economy, 76:169-172.

[9] Russell, Clifford S., Winston Harrington and William J. Vaughan. 1986. Economic Models of Monitoring and Enforcement: Enforcing Pollution Control Laws, Washington, D.C: Resources for the Future.

[10] Gray, Wayne B. and Jay P. Shimshack. 2011. "The Effectiveness of Environmental Monitoring and Enforcement: A Review of the Empirical Evidence," Review of Environmental Economics and Policy 5:3-24.

[11] Gray, Wayne B. and Mary Deily. 1996. "Compliance and Enforcement: Air Pollution Regulation in the U.S. Steel Industry," Journal of Environmental Economics and Management 31: 96-111.

[12] Gray, Wayne and Ron Shadbegian. 2005. "When and Why Do Plants Comply? Paper Mills in the 1980s," Law and Policy 27: 238-61.

[13] Earnhart, Dietrich. 2004. "Regulatory Factors Shaping Environmental Performance at Publicly Owned Treatment Plants," Journal of Environmental Economics and Management 48: 655-81. 
[14] Glicksman, R., and Dietrich Earnhart. 2007. "The Comparative Effectiveness of Government Interventions on Environmental Performance in the Chemical Industry," Stanford Environmental Law Journal 26: 317-71.

[15] Stafford, Sarah. 2002. "The Effect of Punishment on Firm Compliance with Hazardous Waste Regulations," Journal of Environmental Economics and Management 44: 290308.

[16] Gray, Wayne B., and John T. Scholz. 1993. “Does Regulatory Enforcement Work? A Longitudinal Study of OSHA Enforcement," Law and Society Review 27:177-213.

[17] Gray, Wayne B. and John Mendeloff. 2005. "The Declining Effects of OSHA Inspections on Manufacturing Injuries, 1979-1998," Industrial and Labor Relations Review 58:571-587.

[18] Haviland, Amelai et al. 2010. "What kinds of injuries do OSHA inspections prevent?" Journal of Safety Research 41:339-345.

[19] Khanna, Madhu and William Rose Q. Anton. 2002. "Corporate Environmental Management: Regulatory and Market-Based Incentives," Land Economics 78:539558.

[20] Thornton, Dorothy, Neil Gunningham, Robert Kagan. 2005. "General Deterrence and Corporate Environmental Behavior," Law \& Policy 27:262-288.

[21] Manski, Charles F. 2007. Identification for Prediction and Decision. Cambridge, MA: Harvard University Press.

[22] Morgan, Stephen L. and Christopher Winship. 2007. Counterfactuals and Causal Inference: Methods and Principles for Social Research. Cambridge, UK: Cambridge University Press. 